\title{
Penerapan Metode Algoritma Apriori dan FP-Tree Pada Penentuan Pola Pembelian Obat
}

\author{
Rizal Rachman ${ }^{1}$, Nanang Hunaifi ${ }^{2}$ \\ ${ }^{1}$ STMIK Nusa Mandiri \\ e-mail: rizalkhaizuran@gmail.com \\ ${ }^{2}$ Universitas Bina Sarana Informatika \\ e-mail: masnaing@gmail.com
}

\begin{abstract}
Abstrak - Dewasa ini perkembangan industri kesehatan khususnya farmasi meningkat. Itu bisa dilihat dari kemunculan Prodi farmasi di berbagai Akademika civitas. Seiring pertumbuhan industri, informasi tentang produknya menjadi kebutuhan bagi perusahaan. Salah satu kebutuhan penting adalah informasi tentang penjualan obat-obatan dan informasi tentang persiapan atau produksi obat-obatan. Informasi mengenai berapa banyak obat yang akan diproduksi merupakan hal yang sangat penting karena hal ini berkaitan dengan berapa banyak penjualan yang terjadi dalam kurun waktu tertentu atau target pasar yang akan dicapai. Algoritma priori termasuk jenis aturan asosiasi pada data mining. Aturan yang menyatakan hubungan antara berbagai atribut sering disebut analisis afinitas atau analisis pasar basket. Analisis asosiasi atau asosiasi aturan penambangan adalah teknik penambangan data untuk menemukan aturan kombinasi item. Dan FP-Tree adalah struktur penyimpanan data terkompresi. FP-Tree dibangun dengan memetakan setiap catatan transaksi ke setiap jalur spesifik di FP-tree. Berdasarkan data transaksi penjualan obat di pabrik Farma kimia Jakarta, dilakukan analisis menggunakan algoritma Apriori dengan dukungan parameter minimum 10\% dan kepercayaan minimum $50 \%$. Hasil penelitian menghasilkan 7 aturan Asosiasi dengan kombinasi item terbesar hingga 2 item.
\end{abstract}

Kata Kunci: Penambangan Data, Aturan Asosiasi, Analisis Keranjang Pasar, Apriori, FP-Tree

\begin{abstract}
Nowadays the development of the health industry especially pharmaceuticals is increasing. That can be seen from the emergence of pharmacy study programs in various academic communities. As the industry grows, information about its products becomes a necessity for the company. One important requirement is information about drug sales and information about drug preparation or production. Information about how many drugs will be produced is very important because this relates to how many sales occur within a certain period or target market to be achieved. The priori algorithm includes the type of association rule in data mining. Rules that state the relationship between various attributes are often called affinity analyzes or basketball market analysis. Association analysis or association of mining rules is a data mining technique to find the combination of items. And FP-Tree is a compressed data storage structure. FP-Tree is built by mapping each transaction record to each specific path in FP-tree. Based on data on drug sales transactions at the Jakarta Farma chemical factory, an analysis was carried out using the Apriori algorithm with a minimum parameter support of $10 \%$ and a minimum confidence of 50\%. The results of the study resulted in 7 Association rules with the largest combination of items up to 2 items.
\end{abstract}

Keywords: Data Mining, Association Rules, Market Basket Analysis, Apriori, FP-Tree

\section{PENDAHULUAN}

Dewasa ini perkembangan industri kesehatan terutama farmasi meningkat. Hal ini dapat dilihat dari bermunculannya prodi-prodi farmasi di berbagai civitas akademika. Seiring meningkatnya dunia industri maka informasi mengenai produk-produknya menjadi kebutuhan bagi perusahaan. Salah satu yang menjadi kebutuhan penting yaitu informasi mengenai penjualan obat dan informasi mengenai persediaan atau produksi obat. Informasi mengenai berapa banyak obat yang akan diproduksi merupakan hal yang sangat penting karena hal ini berkaitan dengan berapa banyak penjualan yang terjadi dalam kurun waktu tertentu atau target pasar yang akan dicapai(Yay \& Keçeli, 2009).

Perkembangan teknologi informasi yang begitu maju saat ini, menyebabkan tingkat akurasi suatu data sangat dibutuhkan dalam kehidupan sehari-hari. Setiap informasi yang ada menjadi suatu hal penting untuk menentukan setiap keputusan dalam situasi tertentu(Kamagi \& Hansun, 2014).

Data mining berguna untuk memberikan solusi kepada para pemilik perusahaan untuk mengambil keputusan guna meningkatkan bisnis perusahaan. Dengan menggunakan analisis asosiasi dan algoritma 
apriori dapat menghasilkan suatu rekomendasi yang di harapkan dapat membantu manager dalam mendukung keputusan strategi penjualan(Sholik \& Salam, 2018).

Algoritma apriori termasuk jenis aturan asosiasi pada data mining. Aturan yang menyatakan asosiasi antara beberapa atribut sering disebut affinity analysis atau market basket analysis. Analisis asosiasi atau association rule mining adalah teknik data mining untuk menemukan aturan suatu kombinasi item. Penting tidaknya suatu asosiasi dapat diketahui dengan dua tolak ukur, yaitu : support dan confidence(Sujaini, 2016).

FP-Tree merupakan struktur penyimpanan data yang dimampatkan. FP-tree dibangun dengan memetakan setiap data transaksi ke dalam setiap lintasan tertentu dalam FP-tree. Karena dalam setiap transaksi yang dipetakan, mungkin ada transaksi yang memiliki item yang sama, maka lintasannya memungkinkan untuk saling menimpa. Semakin banyak data transaksi yang memiliki item yang sama, maka proses pemampatan dengan struktur data FP-tree semakin efektif(Meilani \& Azmuri, 2015).

Penelitian yang dilakukan oleh (Sulardi, Hendro, \& Umbara, 2017) "Prediksi Kebutuhan Obat Menggunakan Regresi Linier" Pada penelitian system prediksi kebutuhan obat ini system digunakan oleh distributor dan apotik. Data yang diolah berupa data pesanan atau pembelian dan data penjualan. Distributor dapat mengelola fungsi surat pesanan, prediksi dan obat. Data surat pesanan yang berasal dari apotik dijadikan input yang kemudian diprediksi dengan data penjualan yang dimiliki oleh distributor. Kemudian akan diprediksi sehingga akan menghasilkan persamaan dan nilai prediksi. Namun jika persamaan garis regresi bernilai minus maka hasil prediksinya akan di anggap 0 .

Penelitian yang dilakukan oleh (Kamagi \& Hansun, 2014) "Implementasi Data Mining Dengan Algoritma C4.5 Untuk Memprediksi Tingkat Kelulusan Mahasiswa" Pada penelitian data mining dengan algoritma C4.5 dapat diimplementasi untuk memprediksi tingkat kelulusan mahasiswa dengan empat kategori yaitu lulus cepat, lulus tepat, lulus terlambat dan drop out.

Penelitian yang dilakukan oleh (Sholik \& Salam, 2018) "Implementasi Algoritma Apriori Untuk Mencari Asosiasi Barang Yang Dijual Di ECommerce OrderMas" Data Mining Apriori dapat memproses dan di implementasikan dengan menggunakan database transaksi penjualan online ritail barang, karena dapat menemukan kecenderungan pola kombinasi antara itemsets sehingga dapat dijadikan informasi yang sangat penting dalam pengambilan keputusan yang berguna untuk mempersiapkan jenis stok barang apa yang diperlukan kedepanya.

Penelitian yang dilakukan oleh (Iriandi, 2017) "Analisis Asosiasi Pada Transaksi Obat Menggunakan Algoritma Apriori (Study Kasus
:Apotik Trimulya)" Algoritma apriori dalam data mining dapat membantu kinerja penggunaan di dalam merekap transaksi dengan lebih efektif dan efisien jika dibandingkan dengan cara manual.

Penelitian yang dilakukan oleh (Meilani \& Azinar, 2015) "Penentuan Pola Yang Sering Muncul Untuk Penerimaan Kartu Jaminan Kesehatan Masyarakat" Berdasarkan dari hasil pola yang didapat akan digunakan untuk acuan atau informasi sebagai data penunjang pengambil keputusan penerimaan kartu Jamkesmas

Penelitian yang dilakukan oleh (Lestari , 2015) "Penerapan Data Mining menggunakan Algoritma FP-Tree Dan FP-Growth Pada Data Transaksi Penjualan Obat" Data mining dngan algoritma FPGrowth dapat diimplementasikan dengan menggunakan database penjualan obat karena dapat menemukan pola kombinasi itemsets. Sehingga informasi tersebut dapat membantu mengembangkan strategi penjualan terhadap konsumen.

Penelitian yang dilakukan oleh (Samuel, 2017) "Penerapan Struktur FP-Tree Dan Algoritma FPGrowth Dalam Optimasi Penentuan Frequent Itemset" FP-Tree yang terbentuk dapat memanfaatkan data transaksi yang memiliki item yang sama, sehingga penggunaan memori komputer lebih sedikit dan proses pencarian Frequent itemset menjadi lebih cepat.

Penelitian yang dilakukan oleh (Yanto \& Khoiriah, 2015) "Implementasi Data mining Dengan Metode Algoritma Apriori Dalam Menentukan Pola Pembelian Obat" Proses penentuan pola pembelian obat dapat dilakukan dengan menerapkan data mining dengan metode algoritma Apriori. Dengan metode tersebut penentuan pola pembelian dapat dilakukan dengan melihat hasil dan kecenderungan konsumen membeli obat berdasarkan kombinasi 2 itemset.

Penelitian yang dilakukan oleh (Nurchalifatun, 2016) "Penerapan Metode Asosiasi Data Mining Menggunakan Algoritma Apriori Untuk Mengetahui Kombinasi Antar Itemset Pada Pondok Kopi" Penerapan algoritma Apriori pada teknik data mining sangat efisien dan dapat mempercepat proses pembentukan kecenderungan pola kombinasi itemset.

Penelitian yang dilakukan oleh (Despitaria, Sujaini, \& Tursina, 2016) “Analisis Asosiasi Pada Transaksi Obat Menggunakan Data Mining Dengan Algoritma Apriori" Algoritma Apriori dalam data mining dapat digunakan sebagai metode analisis asosiasi untuk mendapatkan kaidah atau aturan yang berisi kombinasi antar obat yang saling berkaitan.

\section{METODOLOGI PENELITIAN}

Penelitian merupakan serangkaian kegiatan yang berisi langkah-langkah ataupun tahapan-tahapan yang dilakukan secara terencana dan sistematis untuk mendapatkan suatu jawaban dari suatu 
permasalahan. Penelitian dilakukan dengan konsep dari data mining menggunakan Knowledge Discovery in Database (KDD) yakni sebuah kerangka kerja sebagai bahan acuan dalam pengkajian dibidang data mining.

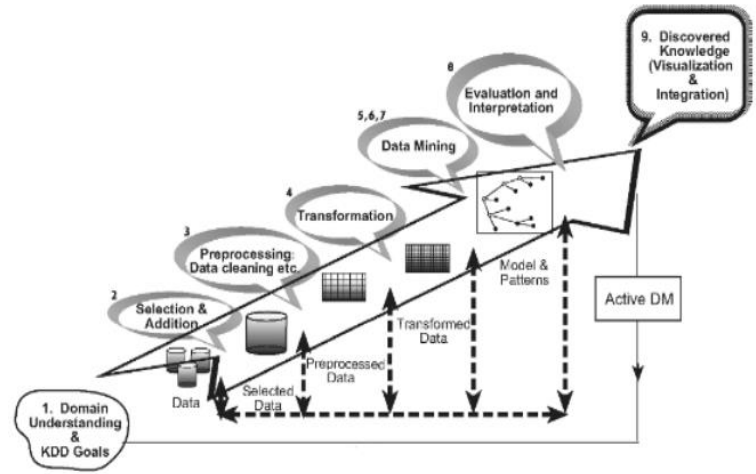

Sumber : (Dhika \& Akhirina, 2015)

Gambar 3.1

Proses KDD (Knowledge Discovery In Databases)

Menurut (Agustin, ., \& Luthfi, 2017) Secara garis besar Knowledge Discovery in Database (KDD) dapat dijelaskan sebagai berikut :

1) Data Selection

Pemilihan (seleksi) data dari sekumpulan data operasional perlu dilakukan sebelum tahap penggalian informasi dalam KDD dimulai. Data hasil selksi yang akan digunakan untuk proses data mining, disimpan dalam suatu berkas terpisah dari basis data operasional.

2) Pre-Processing/Cleaning

Proses cleaning antara lain membuang duplikasi data, memeriksa data yang inkonsisten dan memperbaiki kesalahan pada data. Pada proses ini dilakukan juga proses enrichment, yaitu prosesmemperkaya data yang sudah ada dengan data atau informasi lain yang relevan dan diperlukan untuk KDD.

3) Transformation

Coding adalah proses transformasi pada data yang telah dipilih sehingga data tersebut sesuai untuk proses data mining.

4) Data Mining

Data Mining adalah proses mencari pola atau informasi menarik dalam data terpilih dengan menggunakan teknik atau metode tertentu.

5) Interpretation/Evaluation

Pola informasi yang dihasilkan dari proses data mining diterjemahkan menjadi bentuk yang lebih mudah dimengerti oleh pihak yang berkepentingan.

\section{Perhitungan dengan Algoritma Apriori:}

1. Mencari 3 nilai terbesar yang paling banyak terjual.

a) Menentukan daftar nama obat

b) Menentukan data penjualan obat

2. Melakukan Pengelompokan 2 nama obat yang paling laku terjual.
3. Melakukan Representasi data transaksi.

Setelah pengelompokan 2 nama obat yang dilakukan pada tahap 2 selanjutnya data juga dapat di representasikan

4. Pembuatan Format Tabular

Bila sudah di ketahui nilai penjualan terbesar setiap bulannya maka di buatlah format tabular agar dapat di analisis dengan algoritma apriori

5. Analisis Pola Frekuensi Tinggi

Tahap ini mencari kombinasi item yang memenuhi syarat minimum dari nilai support dalam database. Nilai support sebuah item di peroleh dengan rumus sebagai berikut.

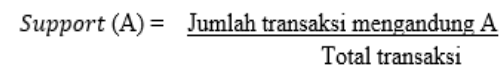

Sementara itu, rumus 2 itemset di peroleh dengan rumus.

Support $(\mathrm{AB})=\frac{\sum \text { transaksi mengandung } \mathrm{A} \text { dan } \mathrm{B}}{\Sigma \text { transaksi }}$ $\Sigma$ transaksi

Dalam pencarian pola frekuensi tinggi akan di hentikan apabila kombinasi sudah tidak memenuhi syarat support yang sudah di tentukan.

6. Pembentukan Aturan Asosiasi

Setelah semua pola frekuensi tinggi di temukan, barulah kita cari aturan asosiasi yang memenuhi syarat minimum untuk confidence dengan menghitung confidence atau asosiałt $\mathrm{A}$ B.

Dengan minimum confidence $50 \%$

Nilai confidence dari aturan $\mathrm{A} \rightarrow \mathrm{B}$ di peroleh dari rumus berikut:

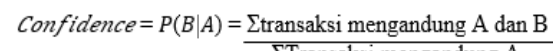

$$
\text { ETransakssi mengandung A }
$$

Pencarian nilai confidence juga di lakukan sampai nilai sudah tidak memnuhi syarat minimum confidence lagi.

7. Aturan Asosiasi Final

Dari analisis yang telah di lakukan dalam tahap ini akan terlihat asosiasi yang terbentuk dengan menggunakan perhitungan algoritma apriori.

Pengelolahan Data dengan Perhitungan FP-Tree FP-Tree merupakan struktur penyimpanan data yang dimampatkan, di bangun dengan memetakan setiap data transaksi ke dalam setiap lintasan tertentu dalam FP-Tree. Karena dalam setiap transaksi yang dipetakan, mungkin ada transaksi yang memiliki item yang sama, maka lintasanya memungkinkan untuk saling menimpa.

Pengolahan data dilakukan dengan menggunakan aplikasi database yaitu Microsoft Excel 2013. Data real transaksi penjualan kemudian disusun kedalam bentuk tabular data, maka data real transaksi penjualan obat dikonversikan ke dalam bentuk 1 dan 0 atau bentuk biner. dimana 1 adalah jika obat dibeli dan 0 jika obat tidak di beli. hasil proses konversi data transaksi penjualan dalam bentuk tabular.

HASIL DAN PEMBAHASAN Pengolahan Data 
Data penjualan yang di pilih merupakan data penjualan obat pada PT. Kimia Farma Plant Jakarta selama 1 tahun, dimulai pada Januari 2018 sampai Desember 2018. Berikut ini merupakan data penjualan selama 1 tahun :

Tabel 4.1 Data Transaksi Penjualan Obat

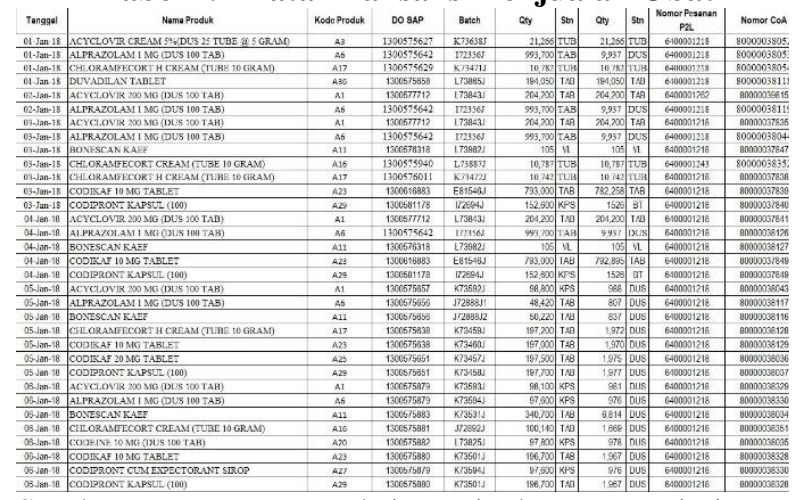

Sumber : Data Transaksi Penjualan PT. Kimia Farma Plant Jakarta (2018)

Tahap dalam menganalisa data dengan algoritma apriori pada penjualan obat dimulai dengan menyeleksi dan membersihkan data-data yang akan dianalisis, kemudian dicari semua jenis item produk asuransi yang ada didalam transaksi penjualan. Selanjutnya dicari jumlah setiap item yang ada pada transaksi penjualan.

Berikut ini merupakan data obat yang sudah di jelaskan Digambar, diberi kode obat agar memudahkan dalam menghitung.

\section{Tabel IV.2 Tabel Data Kode Obat}

\begin{tabular}{|c|l|c|}
\hline NO & NAMA OBAT & KODE OBAT \\
\hline $\mathbf{1}$ & ACYCLOVIR 200 MG (DUS 100 TAB) & A1 \\
\hline $\mathbf{2}$ & ACYCLOVIR 400 MG (DUS 100 TAB) & $\mathbf{A 2}$ \\
\hline $\mathbf{3}$ & $\begin{array}{l}\text { ACYCLOVIR CREAM 5\%(DUS 25 TUBE @ 5 } \\
\text { GRAM) }\end{array}$ & $\mathbf{A 3}$ \\
\hline $\mathbf{4}$ & ALERGINE 10 MG TABLET SALUT SELAPUT & $\mathbf{A 4}$ \\
\hline $\mathbf{5}$ & ALPRAZOLAM 0,5 MG (DUS 100 TAB) & $\mathbf{A 5}$ \\
\hline $\mathbf{6}$ & ALPRAZOLAM 1 MG (DUS 100 TAB) & $\mathbf{A 6}$ \\
\hline $\mathbf{7}$ & AMOXICILLIN 500 MG (DUS 100 TAB) & $\mathbf{A 7}$ \\
\hline $\mathbf{8}$ & AMPICILLIN 500 MG (DUS 100 TAB) & $\mathbf{A 8}$ \\
\hline $\mathbf{9}$ & ANTASIDA DOEN SUSPENSI (BTL 60 ML) & $\mathbf{A 9}$ \\
\hline $\mathbf{1 0}$ & AZITHROMYCIN 500 MG (DUS 20 TAB) & $\mathbf{A 1 0}$ \\
\hline $\mathbf{1 1}$ & BONESCAN KAEF & $\mathbf{A 1 1}$ \\
\hline $\mathbf{1 2}$ & CARDIOSCAN KAEF & $\mathbf{A 1 2}$ \\
\hline $\mathbf{1 3}$ & CEFADROXIL 500 MG (DUS 50 KAPS) & $\mathbf{A 1 3}$ \\
\hline $\mathbf{1 4}$ & CEFIXIME 100 MG (DUS 30 KAPS) & $\mathbf{A 1 4}$ \\
\hline $\mathbf{1 5}$ & CETIRIZINE 10 MG (DUS 30 TAB) & $\mathbf{A 1 5}$ \\
\hline $\mathbf{1 6}$ & CHLORAMFECORT CREAM (TUBE 10 GRAM) & $\mathbf{A 1 6}$ \\
\hline $\mathbf{1 7}$ & CHLORAMFECORT H CREAM (TUBE 10 GRAM) & $\mathbf{A 1 7}$ \\
\hline $\mathbf{1 8}$ & CIPROFLOXACIN 500 MG (DUS 50 TAB) & $\mathbf{A 1 8}$ \\
\hline $\mathbf{1 9}$ & CIPROFLOXACIN 500 MG TSS (EXPORT) & $\mathbf{A 1 9}$ \\
\hline $\mathbf{2 0}$ & CODEINE 10 MG (DUS 100 TAB) & $\mathbf{A 2 0}$ \\
\hline $\mathbf{2 1}$ & CODEINE 15 MG TAB (DUS 100 TAB) & $\mathbf{A 2 1}$ \\
\hline
\end{tabular}

Tabel IV.3 Pola Transaksi Penjualan Obat

\begin{tabular}{|c|c|}
\hline TRANSAKSI & BARANG YANG DIBELI \\
\hline 1 & $\mathrm{~A} 3, \mathrm{~A} 6, \mathrm{~A} 17, \mathrm{~A} 36$ \\
\hline 2 & $\mathrm{~A} 1, \mathrm{~A} 6$ \\
\hline 3 & $A 1, A 6, A 11, A 16, A 17, A 23, A 29$ \\
\hline 4 & $\mathrm{~A} 1, \mathrm{~A} 6, \mathrm{~A} 11, \mathrm{~A} 23, \mathrm{~A} 29$ \\
\hline 5 & $A 1, A 6, A 11, A 17, A 23, A 25, A 29$ \\
\hline 6 & $A 1, A 6, A 11, A 16, A 20, A 23, A 27, A 29$ \\
\hline 7 & $A 1, A 6, A 11, A 16, A 22, A 23, A 27, A 29$ \\
\hline 8 & $\mathrm{~A} 1, \mathrm{~A} 6, \mathrm{~A} 11, \mathrm{~A} 16, \mathrm{~A} 23, \mathrm{~A} 29$ \\
\hline 9 & $A 1, A 6, A 10, A 11, A 16, A 23, A 27, A 28, A 29, A 30$ \\
\hline 10 & $\mathrm{~A} 1, \mathrm{~A} 5, \mathrm{~A} 6, \mathrm{~A} 10, \mathrm{~A} 11, \mathrm{~A} 16, \mathrm{~A} 23, \mathrm{~A} 27, \mathrm{~A} 29, \mathrm{~A} 31$ \\
\hline 11 & $A 1, A 6, A 10, A 11, A 16, A 17, A 23, A 29, A 31$ \\
\hline 12 & $\mathrm{~A} 1, \mathrm{~A} 2, \mathrm{~A} 6, \mathrm{~A} 7, \mathrm{~A} 11, \mathrm{~A} 17, \mathrm{~A} 20, \mathrm{~A} 22, \mathrm{~A} 23, \mathrm{~A} 28, \mathrm{~A} 29, \mathrm{~A} 32, \mathrm{~A} 35$ \\
\hline 13 & $A 2, A 7, A 11, A 12, A 17, A 23, A 24, A 29, A 30, A 33$ \\
\hline 14 & $\mathrm{~A} 2, \mathrm{~A} 7, \mathrm{~A} 12, \mathrm{~A} 24, \mathrm{~A} 30, \mathrm{~A} 34$ \\
\hline 15 & $A 2, A 7, A 10, A 12, A 17, A 20, A 24, A 30, A 35$ \\
\hline 16 & $\mathrm{~A} 2, \mathrm{~A} 7, \mathrm{~A} 12, \mathrm{~A} 24, \mathrm{~A} 30, \mathrm{~A} 36$ \\
\hline 17 & $A 2, A 7, A 10, A 12, A 17, A 20, A 22, A 24, A 25, A 37$ \\
\hline 18 & $\mathrm{~A} 2, \mathrm{~A} 7, \mathrm{~A} 12, \mathrm{~A} 24, \mathrm{~A} 25$ \\
\hline 19 & $\mathrm{~A} 2, \mathrm{~A} 7, \mathrm{~A} 12, \mathrm{~A} 16, \mathrm{~A} 22, \mathrm{~A} 24, \mathrm{~A} 26, \mathrm{~A} 29$ \\
\hline 20 & $\mathrm{~A} 2, \mathrm{~A} 7, \mathrm{~A} 10, \mathrm{~A} 12, \mathrm{~A} 16, \mathrm{~A} 24, \mathrm{~A} 27$ \\
\hline 21 & $\mathrm{~A} 2, \mathrm{~A} 7, \mathrm{~A} 12, \mathrm{~A} 16, \mathrm{~A} 24, \mathrm{~A} 28$ \\
\hline 22 & $\mathrm{~A} 2, \mathrm{~A} 7, \mathrm{~A} 12, \mathrm{~A} 16, \mathrm{~A} 20, \mathrm{~A} 22, \mathrm{~A} 24, \mathrm{~A} 29$ \\
\hline
\end{tabular}

Format Tabular data transaksi penjualan, bila dibentuk akan tampak seperti Tabel IV. 4 berikut ini :

\section{Tabel IV.4 Tabel Format Tabular Data Transaksi}

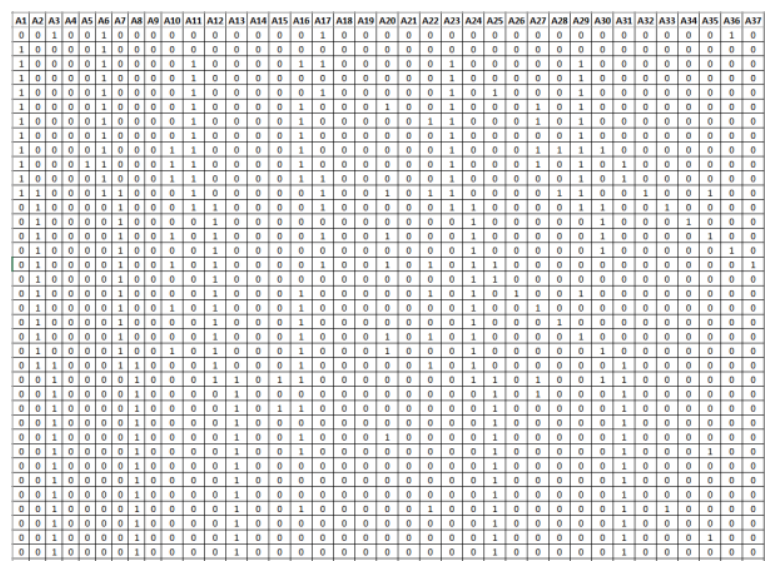

1. Pembentukan 1 Itemset

Proses pembentukan $\mathrm{C} 1$ atau disebut dengan 1 itemset dengan jumlah minimum support $=10 \%$ Dengan rumus sebagai berikut :

$$
\text { Support }(A)=\frac{\sum \text { Jumlah transaksi mengandung A }}{\sum \text { Total transaksi }} * 100 \%
$$

Berikut merupakan perhitungan pembentukan 1 itemset :

$$
\begin{aligned}
& S(\mathrm{~A} 1)=\frac{\sum \text { Transaksi A1 }}{\sum 273}=\frac{30}{273} * 100 \%=11 \% \\
& S(\mathrm{~A} 2)=\frac{\sum \text { Transaksi A2 }}{\sum 273}=\frac{63}{273} * 100 \%=23 \% \\
& S(\mathrm{~A} 3)=\frac{\sum \text { Transaksi A3 }}{\sum 273}=\frac{82}{273} * 100 \%=30 \%
\end{aligned}
$$


Berdasarkan uraian diatas, maka dapat dibuat table IV.5 :

Tabel IV.5 Support Dari Tiap Itemset

\begin{tabular}{|c|c|c|c|c|c|}
\hline $\begin{array}{l}\text { KODE } \\
\text { OBAT }\end{array}$ & JUMLAH & SUPPORT & $\begin{array}{l}\text { KODE } \\
\text { OBAT }\end{array}$ & JUMLAH & SUPPORT \\
\hline $\mathrm{A} 1$ & 30 & $11 \%$ & A20 & 51 & $19 \%$ \\
\hline A2 & 63 & $23 \%$ & A21 & 24 & $9 \%$ \\
\hline A3 & 82 & $30 \%$ & A22 & 27 & $10 \%$ \\
\hline A4 & 51 & $19 \%$ & $\mathrm{~A} 23$ & 51 & $19 \%$ \\
\hline A5 & 38 & $14 \%$ & A24 & 53 & $19 \%$ \\
\hline A6 & 50 & $18 \%$ & A25 & 41 & $15 \%$ \\
\hline A7 & 82 & $30 \%$ & A26 & 61 & $22 \%$ \\
\hline A8 & 65 & $24 \%$ & A27 & 37 & $14 \%$ \\
\hline A9 & 55 & $20 \%$ & A28 & 34 & $12 \%$ \\
\hline $\mathrm{A} 10$ & 55 & $20 \%$ & A29 & 60 & $22 \%$ \\
\hline A11 & 36 & $13 \%$ & $\mathrm{~A} 30$ & 56 & $21 \%$ \\
\hline A12 & 34 & $12 \%$ & A31 & 46 & $17 \%$ \\
\hline $\mathrm{A} 13$ & 72 & $26 \%$ & A32 & 39 & $14 \%$ \\
\hline A14 & 68 & $25 \%$ & A33 & 23 & $8 \%$ \\
\hline A15 & 50 & $18 \%$ & A34 & 26 & $10 \%$ \\
\hline A16 & 84 & $31 \%$ & A35 & 44 & $16 \%$ \\
\hline A17 & 46 & $17 \%$ & A36 & 40 & $15 \%$ \\
\hline A18 & 42 & $15 \%$ & A37 & 27 & $10 \%$ \\
\hline A19 & 23 & $8 \%$ & & & \\
\hline
\end{tabular}

Dari proses pembentukan item pada tabel 4 dengan minimum support $10 \%$ dapat diketahui yang memenuhi standar minimum support yaitu ada 31 jenis, dari ke 31 jenis tersebut kemudian dibentuk kombinasi 2 item. Gambar berikut merupakan jenis item yang memenuhi standart minimum support :

Tabel III.6 Data Yang Memenuhi Minimal Support 1 Itemset 10\%

\begin{tabular}{|c|c|c|c|c|c|}
\hline $\begin{array}{l}\text { KODE } \\
\text { OBAT }\end{array}$ & JUMLAH & SUPPORT & $\begin{array}{l}\text { KODE } \\
\text { OBAT }\end{array}$ & JUMLAH & SUPPORT \\
\hline A1 & 30 & $11 \%$ & A17 & 46 & $17 \%$ \\
\hline $\mathrm{A} 2$ & 63 & $23 \%$ & A18 & 42 & $15 \%$ \\
\hline A3 & 82 & $30 \%$ & A19 & 51 & $19 \%$ \\
\hline A4 & 51 & $19 \%$ & A20 & 51 & $19 \%$ \\
\hline A5 & 38 & $14 \%$ & A 21 & 53 & $19 \%$ \\
\hline A6 & 50 & $18 \%$ & A22 & 41 & $15 \%$ \\
\hline A7 & 82 & $30 \%$ & A23 & 61 & $22 \%$ \\
\hline A8 & 65 & $24 \%$ & A24 & 37 & $13 \%$ \\
\hline A9 & 55 & $20 \%$ & A25 & 34 & $12 \%$ \\
\hline $\mathrm{A} 10$ & 55 & $20 \%$ & A26 & 60 & $22 \%$ \\
\hline A11 & 36 & $13 \%$ & A27 & 56 & $20 \%$ \\
\hline A12 & 34 & $12 \%$ & A28 & 46 & $17 \%$ \\
\hline $\mathrm{A} 13$ & 72 & $26 \%$ & A29 & 39 & $14 \%$ \\
\hline A14 & 68 & $25 \%$ & A30 & 44 & $16 \%$ \\
\hline A15 & 50 & $18 \%$ & A31 & 40 & $15 \%$ \\
\hline A16 & 84 & $31 \%$ & & & \\
\hline
\end{tabular}

2. Kombinasi 2 itemset

Proses pembentukan C2 atau disebut dengan 2 itemset dengan jumlah , minimum support $=$ $10 \%$

Dapat diselesaikan dengan rumus sebagai berikut :

Support $(\mathrm{A}, \mathrm{B})=\mathrm{P}(\mathrm{A} \cap \mathrm{B})$

Berikut merupakan perhitungan pembentukan C2 atau 2 itemset :

$$
\begin{aligned}
& \operatorname{Support}(\mathrm{AB})=\frac{\sum \text { Jumlah transaksi mengandung A B }}{\sum \text { To }} * 100 \% \\
& \sum \text { Total transaksi } \\
& \text { Support (A1_A2) }=\frac{\sum \text { Jumlah transaksi A1_A2 }}{\sum 273}={ }_{273}^{3} * 100 \%=1 \% \\
& \operatorname{Support}(\mathrm{A} 1 \mathrm{~A} 3)=\frac{\sum \text { Jumlah transaksi A1.A3 }}{\sum 273}=\frac{0}{273} * 100 \%=0 \% \\
& \frac{\sum \text { Jumlah transalksi Alda4 }}{\sum 273}={ }^{3}{ }^{3} 100 \%=1 \%
\end{aligned}
$$

Berdasarkan uraian diatas, maka dapat dibuat Tabel IV.7 :

Tabel IV.7 Calon 2 Itemset

\begin{tabular}{|c|c|c|c|c|c|c|c|}
\hline NO & ITEMSET & JUMLAH & SUPPORT & NO & ITEMSET & JUMLAH & SUPPORT \\
\hline $\mathbf{1}$ & A1-A2 & 3 & $1 \%$ & $\mathbf{5 1}$ & A2-A26 & 23 & $8 \%$ \\
\hline $\mathbf{2}$ & A1-A3 & 0 & $0 \%$ & $\mathbf{5 2}$ & A2-A27 & 6 & $2 \%$ \\
\hline $\mathbf{3}$ & A1-A4 & 3 & $1 \%$ & $\mathbf{5 3}$ & A2-A28 & 11 & $4 \%$ \\
\hline $\mathbf{4}$ & A1-A5 & 4 & $1 \%$ & $\mathbf{5 4}$ & A2-A29 & 11 & $4 \%$ \\
\hline $\mathbf{5}$ & A1-A6 & 12 & $4 \%$ & $\mathbf{5 5}$ & A2-A30 & 8 & $3 \%$ \\
\hline $\mathbf{6}$ & A1-A7 & 8 & $3 \%$ & $\mathbf{5 6}$ & A2-A31 & 6 & $2 \%$ \\
\hline $\mathbf{7}$ & A1-A8 & 12 & $4 \%$ & $\mathbf{5 7}$ & A2-A32 & 4 & $1 \%$ \\
\hline $\mathbf{8}$ & A1-A9 & 2 & $1 \%$ & $\mathbf{5 8}$ & A2-A35 & 5 & $2 \%$ \\
\hline $\mathbf{9}$ & A1-A10 & 4 & $1 \%$ & $\mathbf{5 9}$ & A2-A36 & 6 & $2 \%$ \\
\hline $\mathbf{1 0}$ & A1-A11 & 11 & $4 \%$ & $\mathbf{6 0}$ & A3-A4 & 4 & $1 \%$ \\
\hline $\mathbf{1 1}$ & A1-A12 & 5 & $2 \%$ & $\mathbf{6 1}$ & A3-A5 & 13 & $5 \%$ \\
\hline $\mathbf{1 2}$ & A1-A13 & 0 & $0 \%$ & $\mathbf{6 2}$ & A3-A6 & 4 & $1 \%$ \\
\hline $\mathbf{1 3}$ & A1-A14 & 0 & $0 \%$ & $\mathbf{6 3}$ & A3-A7 & 11 & $4 \%$ \\
\hline $\mathbf{1 4}$ & A1-A15 & 0 & $0 \%$ & $\mathbf{6 4}$ & A3-A8 & 25 & $9 \%$ \\
\hline $\mathbf{1 5}$ & A1-A16 & 16 & $6 \%$ & $\mathbf{6 5}$ & A3-A9 & 24 & $9 \%$ \\
\hline $\mathbf{1 6}$ & A1-A17 & 9 & $3 \%$ & $\mathbf{6 6}$ & A3-A10 & 13 & $5 \%$ \\
\hline $\mathbf{1 7}$ & A1-A18 & 0 & $0 \%$ & $\mathbf{6 7}$ & A3-A11 & 8 & $3 \%$ \\
\hline $\mathbf{1 8}$ & A1-A20 & 10 & $4 \%$ & $\mathbf{6 8}$ & A3-A12 & 3 & $1 \%$ \\
\hline $\mathbf{1 9}$ & A1-A23 & 12 & $4 \%$ & $\mathbf{6 9}$ & A3-A13 & 43 & $16 \%$ \\
\hline $\mathbf{2 0}$ & A1-A24 & 0 & $0 \%$ & $\mathbf{7 0}$ & A3-A14 & 17 & $6 \%$ \\
\hline $\mathbf{2 1}$ & A1-A25 & 5 & $2 \%$ & $\mathbf{7 1}$ & A3-A15 & 13 & $5 \%$ \\
\hline
\end{tabular}

Minimal Support yang ditentukan adalah $10 \%$, jadi kombinasi 2 itemset yang tidak memenuhi minimal support akan dihilangkan, terlihat seperti Tabel IV.7 dibawah ini :

Tabel IV.8 Minimal Support 2 Itemset 10\%

\begin{tabular}{|c|c|c|c|}
\hline NO & ITEMSET & JUMLAH & SUPPORT \\
\hline $\mathbf{3 5}$ & A2-A7 & 31 & $11 \%$ \\
\hline $\mathbf{6 9}$ & A3-A13 & 43 & $16 \%$ \\
\hline $\mathbf{7 4}$ & A3-A18 & 31 & $11 \%$ \\
\hline $\mathbf{8 6}$ & A3-A35 & 28 & $10 \%$ \\
\hline $\mathbf{1 7 2}$ & A7-A14 & 30 & $11 \%$ \\
\hline $\mathbf{1 7 9}$ & A7-A24 & 28 & $10 \%$ \\
\hline $\mathbf{1 8 5}$ & A7-A30 & 28 & $10 \%$ \\
\hline $\mathbf{1 9 7}$ & A8-A16 & 40 & $15 \%$ \\
\hline
\end{tabular}

Setelah semua pola frekuensi tinggi ditemukan, baru dicari aturan asosiasi yang memenuhi syarat minimum Confidence dengan menghitung Confidence aturan asosiatif $\mathrm{A} \rightarrow \mathrm{B}$.

Minimal Confidence $=50 \%$

Nilai Confidence dari aturan $\mathrm{A} \rightarrow \mathrm{B}$ diperoleh dengan rumus sebagai berikut :

$\sum$ Jumlah transaksi mengandung A dan B

Confidence $\mathrm{P}(\mathrm{A} / \mathrm{B})=$ — $100 \%$

$\sum$ Transaksi A

Berikut merupakan perhitungan Confidence : 


$$
\begin{aligned}
& \text { Confidence } \mathrm{P}(\mathrm{A} 2 \mathrm{~A} 7)=\frac{\sum \text { Transaksi A2 dan A7 }}{\sum \mathrm{A} 2}=\frac{31}{63} * 100 \%=49 \% \\
& \text { Confidence } \mathrm{P}(\mathrm{A} 7 \mathrm{~A} 2)=\frac{\sum \text { Transaksi A7 dan } \mathrm{A} 2}{\sum \mathrm{A} 7}=\frac{31}{82} * 100 \%=38 \% \\
& \text { Confidence } \mathrm{P}(\mathrm{A} 3 \mathrm{~A} 13)=\frac{\sum \text { Transaksi A3 dan } \mathrm{A} 13}{\sum \mathrm{A} 3}=\frac{43}{82} * 100 \%=52 \%
\end{aligned}
$$

Dari kombinasi 2 itemset yang telah ditemukan, dapat dilihat besarnya confidence dari calon aturan asosiasi seperti tampak pada Tabel IV.8 di bawah ini

\section{Tabel IV.9 Calon Aturan Asosiasi}

\begin{tabular}{|r|c|c|c|}
\hline NO & ITEMSET & JUMLAH & CONFIDENCE \\
\hline 1 & A2-A7 & $(31 / 63) * 100$ & $49 \%$ \\
\hline 2 & A7-A2 & $(31 / 82)^{*} 100$ & $38 \%$ \\
\hline 3 & A3-A13 & $(43 / 82)^{*} 100$ & $52 \%$ \\
\hline 4 & A13-A3 & $(43 / 72)^{*} 100$ & $60 \%$ \\
\hline 5 & A3-A18 & $(31 / 82)^{*} 100$ & $38 \%$ \\
\hline 6 & A18-A3 & $(31 / 42)^{*} 100$ & $74 \%$ \\
\hline 7 & A3-A35 & $(28 / 82)^{*} 100$ & $34 \%$ \\
\hline 8 & A35-A3 & $(28 / 44) * 100$ & $64 \%$ \\
\hline 9 & A7-A14 & $(30 / 82)^{*} 100$ & $37 \%$ \\
\hline 10 & A14-A7 & $(30 / 68) * 100$ & $44 \%$ \\
\hline 11 & A7-A24 & $(28 / 53)^{*} 100$ & $53 \%$ \\
\hline 12 & A24-A7 & $(28 / 82)^{*} 100$ & $34 \%$ \\
\hline 13 & A7-A30 & $(28 / 82)^{*} 100$ & $34 \%$ \\
\hline 14 & A30-A7 & $(28 / 56) * 100$ & $50 \%$ \\
\hline 15 & A8-A16 & $(40 / 65) * 100$ & $62 \%$ \\
\hline 16 & A16-A8 & $(40 / 84)^{*} 100$ & $48 \%$ \\
\hline
\end{tabular}

Berdasarkan dari calon aturan asosiasi pada Tabel IV.8 maka yang memenuhi minimal confidence $50 \%$ dapat dilihat pada Tabel IV.9 dibawah ini :

Tabel IV.10 Aturan Asosiasi Final

\begin{tabular}{|c|c|c|c|}
\hline NO & ITEMSET & JUMLAH & CONFIDENCE \\
\hline $\mathbf{1}$ & Jika meniual A18 maka akan meniual A3 & $(42 / 31)^{*} 100$ & $74 \%$ \\
\hline $\mathbf{2}$ & Jika meniual A35 maka akan meniual A3 & $(44 / 28)^{*} 100$ & $64 \%$ \\
\hline $\mathbf{3}$ & Jika meniual A8 maka akan meniual A16 & $(65 / 40)^{*} 100$ & $62 \%$ \\
\hline $\mathbf{4}$ & Jika meniual A13 maka akan meniual A3 & $(72 / 43) * 100$ & $60 \%$ \\
\hline $\mathbf{5}$ & Jika meniual A24 maka akan meniual A7 & $(53 / 28)^{*} 100$ & $53 \%$ \\
\hline $\mathbf{6}$ & Jika meniual A3 maka akan meniual A13 & $(82 / 43)^{*} 100$ & $52 \%$ \\
\hline $\mathbf{7}$ & Jika meniual A30 maka akan meniual A7 & $(56 / 28)^{*} 100$ & $50 \%$ \\
\hline
\end{tabular}

\section{Pengolahan Data Dengan Rapidminer}

Setelah hasil perhitungan algoritma apriori di dapat dengan perhitungan manual maka akan lebih akurat dengan software Rapidminer. Dengan cara menginput tabel tabular ke dalam Ms.Excel yang kemudian di masukan ke software Rapidminer, hasil proses konversi data transaksi penjualan dalam bentuk tabular data dapat dilihat pada Tabel IV.4. Kemudian buka aplikasi Rapidminer dan pilih impor data untuk memasukan tabular.

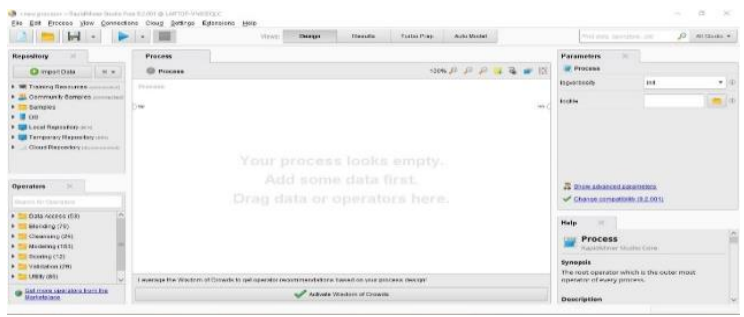

\section{Gambar IV.5 Tampilan Rapidminer}

Kemudian akan tampil seperti berikut ini, pilih data tabular yang akan digunakan lalu next hingga finish

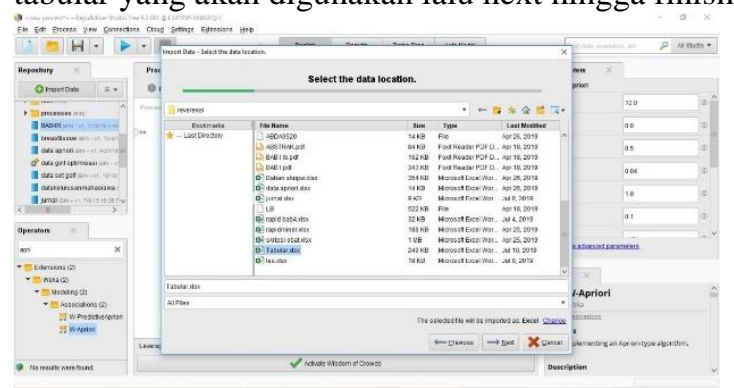

Gambar IV.6 Tampilan Import Data

Kemudian drag dataset yang akan digunakan ke design, lalu tambahkan Numerical to Binominal dan tambahkan algoritma apriori, lalu hubungkan semua, jika sudah klik lambang play.

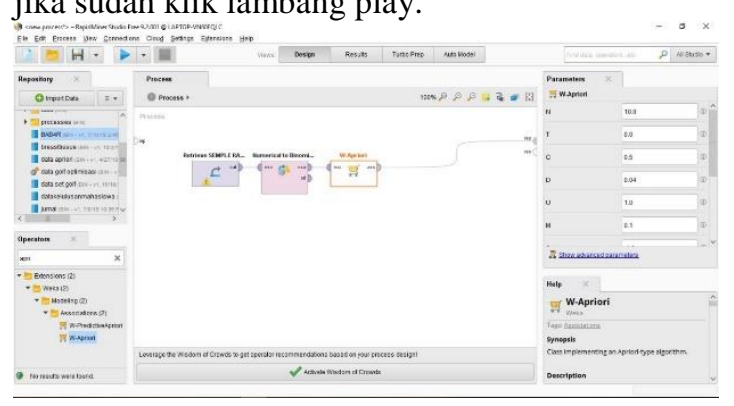

Akan muncul hasil seperti ini

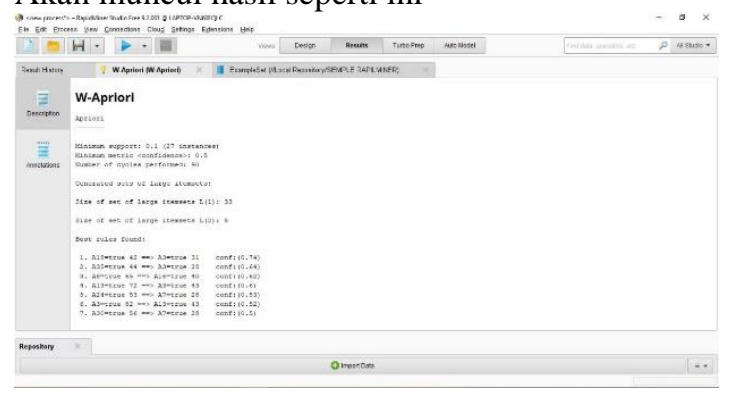

Pengolahan Data Dengan Perhitungan FP-Tree Pengolahan data dilakukan dengan menggunakan aplikasi database yaitu Microsoft Excel 2013. Data real transaksi penjualan kemudian disusun kedalam bentuk tabular. Hasil proses konversi data transaksi penjualan dalam bentuk tabular data dapat dilihat pada Tabel IV.4. Kemudian menentukan frekuensi setiap item dari keseluruhan transaksi. 
Tabel IV.11 Frekuensi Fp-Tree Dari Keseluruhan Transaksi

\begin{tabular}{|c|c|c|c|c|c|}
\hline NO & $\begin{array}{l}\text { KODE } \\
\text { OBAT }\end{array}$ & JUMLAH & NO & $\begin{array}{l}\text { KODE } \\
\text { OBAT }\end{array}$ & JUMLAH \\
\hline $\mathbf{1}$ & A16 & 84 & $\mathbf{2 0}$ & A31 & 46 \\
\hline $\mathbf{2}$ & A3 & 82 & $\mathbf{2 1}$ & A35 & 44 \\
\hline $\mathbf{3}$ & A7 & 82 & $\mathbf{2 2}$ & A18 & 42 \\
\hline $\mathbf{4}$ & A13 & 72 & $\mathbf{2 3}$ & A25 & 41 \\
\hline $\mathbf{5}$ & A14 & 68 & $\mathbf{2 4}$ & A36 & 40 \\
\hline $\mathbf{6}$ & A8 & 65 & $\mathbf{2 5}$ & A32 & 39 \\
\hline $\mathbf{7}$ & A2 & 63 & $\mathbf{2 6}$ & A5 & 38 \\
\hline $\mathbf{8}$ & A26 & 61 & $\mathbf{2 7}$ & A27 & 37 \\
\hline $\mathbf{9}$ & A29 & 60 & $\mathbf{2 8}$ & A11 & 36 \\
\hline $\mathbf{1 0}$ & A30 & 56 & $\mathbf{2 9}$ & A12 & 34 \\
\hline $\mathbf{1 1}$ & A9 & 55 & $\mathbf{3 0}$ & A28 & 34 \\
\hline $\mathbf{1 2}$ & A10 & 55 & $\mathbf{3 1}$ & A1 & 30 \\
\hline $\mathbf{1 3}$ & A24 & 53 & $\mathbf{3 2}$ & A22 & 27 \\
\hline $\mathbf{1 4}$ & A4 & 51 & $\mathbf{3 3}$ & A37 & 27 \\
\hline $\mathbf{1 5}$ & A20 & 51 & $\mathbf{3 4}$ & A34 & 26 \\
\hline $\mathbf{1 6}$ & A23 & 51 & $\mathbf{3 5}$ & A21 & 24 \\
\hline $\mathbf{1 7}$ & A6 & 50 & $\mathbf{3 6}$ & A19 & 23 \\
\hline $\mathbf{1 8}$ & A15 & 50 & $\mathbf{3 7}$ & A33 & 23 \\
\hline $\mathbf{1 9}$ & A17 & 46 & & & \\
\cline { 1 - 2 } & & & & & \\
\hline
\end{tabular}

Agar memudahkan Pembangunan Tree, dipilih 10 jenis obat terlaris.

Tabel IV.12. 10 Obat Terlaris

\begin{tabular}{|c|c|c|}
\hline NO & KODE OBAT & JUMLAH \\
\hline $\mathbf{1}$ & A16 & 84 \\
\hline $\mathbf{2}$ & A3 & 82 \\
\hline $\mathbf{3}$ & A7 & 82 \\
\hline $\mathbf{4}$ & A13 & 72 \\
\hline $\mathbf{5}$ & A14 & 68 \\
\hline $\mathbf{6}$ & A8 & 65 \\
\hline $\mathbf{7}$ & A2 & 63 \\
\hline $\mathbf{8}$ & A26 & 61 \\
\hline $\mathbf{9}$ & A29 & 60 \\
\hline $\mathbf{1 0}$ & A30 & 56 \\
\hline
\end{tabular}

Kemudian urutkan item pada tiap transaksi berdasarkan frekuensi paling tinggi.

Tabel IV.13 Data Transaksi Setelah Proses Filter

\begin{tabular}{|c|c|c|c|}
\hline TRANSAKSI & BARANG YANG DIBEU & TRANSAKSI & BARANG YANG DIBEL \\
\hline 1 & A3 & 51 & A14, A26 \\
\hline 3 & A16, A29 & 52 & A14, A26 \\
\hline 4 & A29 & 53 & A14, A26 \\
\hline 5 & A29 & 54 & A26 \\
\hline 6 & A16, A29 & 55 & $A 16, A 3$ \\
\hline 7 & A16, A29 & 60 & A29 \\
\hline 8 & A16, A29 & 61 & A26 \\
\hline 9 & $\mathrm{~A} 16, \mathrm{~A} 29, \mathrm{~A} 30$ & 66 & A26, A29 \\
\hline 10 & A16, A29 & 67 & A26 \\
\hline 11 & A16, A29 & 68 & A16 \\
\hline 12 & $A 7, A 2, A 29$ & 69 & A16 \\
\hline 13 & $A 7, A 2, A 29, A 30$ & 70 & A16 \\
\hline 14 & $\mathrm{~A} 7, \mathrm{A2}, \mathrm{A} 30$ & 71 & A16 \\
\hline 15 & $\mathrm{~A} 7, \mathrm{A2}, \mathrm{A} 30$ & 72 & $\mathrm{~A} 16, \mathrm{~A} 2, \mathrm{~A} 26$ \\
\hline 16 & $\mathrm{~A} 7, \mathrm{A2}, \mathrm{A} 30$ & 73 & A16 \\
\hline 17 & $\mathrm{~A} 7, \mathrm{A2}$ & 74 & A16, A2 \\
\hline 18 & $\mathrm{~A} 7, \mathrm{~A} 2$ & 75 & $\mathrm{~A} 16, \mathrm{~A} 2$ \\
\hline 19 & $\mathrm{~A} 16, \mathrm{~A} 7, \mathrm{A2}, \mathrm{A} 26, \mathrm{~A} 29$ & 76 & $\mathrm{~A} 16, \mathrm{~A} 30$ \\
\hline 20 & $\mathrm{~A} 16, \mathrm{~A} 7, \mathrm{~A} 2$ & 77 & $\mathrm{~A} 16, \mathrm{~A} 26, \mathrm{~A} 30$ \\
\hline 21 & $\mathrm{~A} 16, \mathrm{~A} 7, \mathrm{~A} 2$ & 78 & A16 \\
\hline 22 & $A 16, A 7, A 2, A 29$ & 80 & A2 \\
\hline 23 & $\mathrm{~A} 16, \mathrm{~A} 7, \mathrm{~A} 2, \mathrm{~A} 30$ & 81 & A2 \\
\hline 24 & $\mathrm{~A} 16, \mathrm{~A} 3, \mathrm{~A} 7, \mathrm{~A} 8, \mathrm{~A} 2$ & 82 & A26 \\
\hline 25 & $\mathrm{~A} 16, \mathrm{~A} 3, \mathrm{~A} 13, \mathrm{~A} 8, \mathrm{~A} 30$ & 84 & A7 \\
\hline 26 & $\mathrm{~A} 3, \mathrm{~A} 13, \mathrm{~A} 8$ & 90 & A8 \\
\hline 27 & $\mathrm{~A} 16, \mathrm{~A} 3, \mathrm{~A} 13, \mathrm{~A} 8$ & 91 & A7 \\
\hline 28 & $\mathrm{~A} 3, \mathrm{~A} 13, \mathrm{~A} 8$ & 92 & $A 8, A 30$ \\
\hline 29 & $\mathrm{~A} 16, \mathrm{~A} 3, \mathrm{~A} 13, \mathrm{~A} 8$ & 94 & A7 \\
\hline 30 & $\mathrm{~A} 16, \mathrm{~A} 3, \mathrm{~A} 13, \mathrm{~A} 8$ & 95 & $A 7, A 2$ \\
\hline 31 & $\mathrm{~A} 3, \mathrm{~A} 13, \mathrm{~A} 8$ & 96 & $A 8, A 2, A 30$ \\
\hline 32 & $A 3, A 13, A 8$ & 97 & A2 \\
\hline
\end{tabular}

Pembangunan Tree dari seluruh transaksi tersebut adalah:

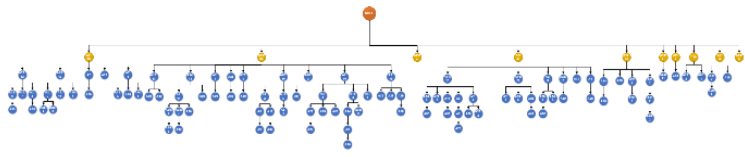

Gambar IV.9 Tampilan Hasil Dari Seluruh Transaksi

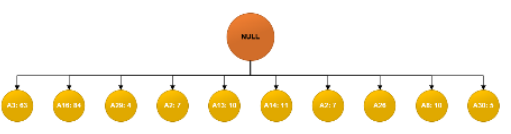

Gambar IV.10 Tampilan Hasil Dari Seluruh Transaksi Terbanyak

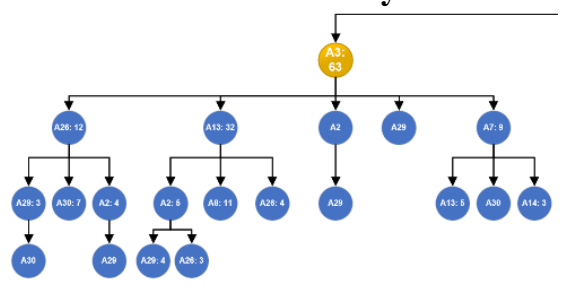

Gambar IV.11 Tampilan Hasil Dari Transaksi A3

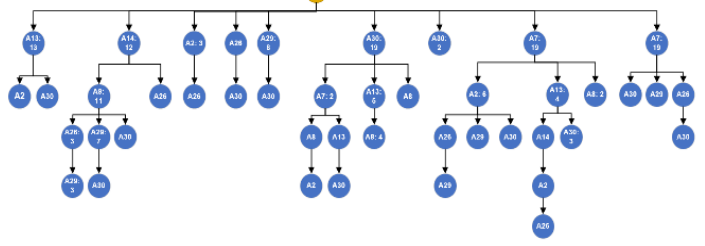

Gambar IV.12 Tampilan Hasil Dari Transaksi

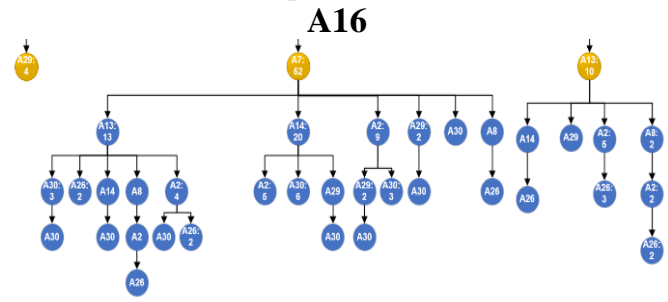

Gambar IV.13 Tampilan Hasil Dari Transaksi

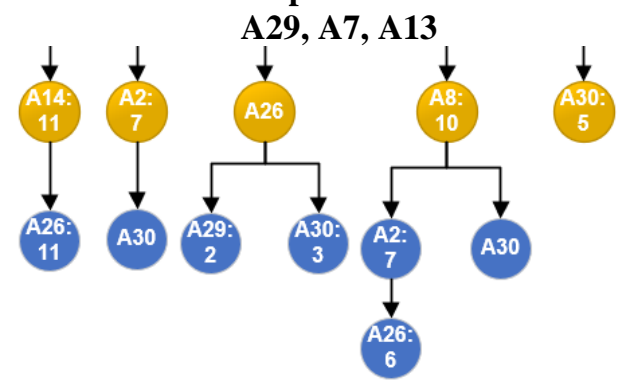

Gambar IV.14 Tampilan Hasil Dari Transaksi A14, A2, A26, A8, A30

\section{KESIMPULAN}

Berdasarkan hasil analisa dan pengujian terhadap analisis asosiasi pada transaksi obat dapat 
menghasilkan pola kombinasi itemset dan rules sebagai ilmu pengetahuan dan informasi yang bermanfaat dari data penjualan atau transaksi pada suatu toko atau perusahaan, serta dapat diimplementasikan dengan menggunakan database penjualan obat karena dapat menemukan pola kombinasi itemset. Sehingga informasi tersebut dapat membantu mengembangkan strategi penjualan terhadap konsumen.

\section{REFERENSI}

Agustin, Y. H., . K., \& Luthfi, E. T. (2017). Klasifikasi Penerimaan Mahasiswa Baru Menggunakan Algortima C4.5 Dan Adaboost (Studi Kasus: STMIK XYZ). CSRID (Computer Science Research and Its Development Journal), 9(1), 1. https://doi.org/10.22303/csrid.9.1.2017.1-11

Despitaria, Sujaini, H., \& Tursina. (2016). Analisis Asosiasi Pada Transaksi Obat Menggunakan Data Mining Dengan Menggunakan Algoritma Apriori. Analisis Asosiasi, 2.

Dhika, H., \& Akhirina, T. Y. (2015). Kajian Penerapan Algoritma Data Mining Terhadap Pemilihan Mitra Kerja Penyedia Jasa Transportasi, 6-8.

Iriandi, D. (2017). Analisis Asosiasi Pada Transaksi Obat Menggunakan Algoritma Apriori (Studi Kasus : Apotek Trimulya). Analisis Asosiasi, 3.

Kamagi, D. H., \& Hansun, S. (2014). Implementasi Data Mining dengan Algoritma C4.5 untuk Memprediksi Tingkat Kelulusan Mahasiswa. Jurnal ULTIMATICS, 6(1), 15-20. https://doi.org/10.31937/ti.v6i1.327

Lestari , Y. D. (2015). Penerapan Data Mining Menggunakan Algoritma FP-Tree dan FPGrowth Pada Data Transaksi Penjualan Obat. Penerapan Data Mining, 60.

Meilani, B. D., \& Azmuri, W. (2015). Penentuan Pola Yang Sering Muncul Untuk Penerima Kartu Jaminan Kesehatan Masyarakat (JAMKESMAS) Menggunakan Metode FPGrowth. Seminar Nasional "Inovasi Dalam Desain Dan Teknologi, " 424-431.

Nurchalifatun, F. (2016). Penerapan Metode Asosiasi Data Mining Menggunakan Algoritma Apriori Untuk Mengetahui
Kombinasi Antar Itemset Pada Pondok Kopi. Penerapan Metode Asosiasi, 2-3.

Samuel, D. (2017). Penerapan Struktur FP-Tree Dan Algoritma FP-Growth dalam optimasi Penetuan Frequent Itemset. Penerpan Dtruktur FP-Tree, 1-2.

Sholik, M., \& Salam, A. (2018). Implementasi Algoritma Apriori untuk Mencari Asosiasi Barang yang Dijual di E-commerce OrderMas. Techno.Com, 17(2), 158-170.

Sujaini, H. (2016). Analisis Asosiasi pada Transaksi Obat Menggunakan, 1(1). Retrieved from https://scholar.google.co.id/scholar?hl=id\&as_ $\mathrm{sdt}=0 \% 2 \mathrm{C} 5 \& \mathrm{q}=\% 28$ Iriandi $\% 2 \mathrm{C}+2017 \% 29+{ }^{\circ}$ Analisis+Asosiasi+Pada+Transaksi+Obat+Me nggunakan+Algoritma+Apriori+\%28Study+K asus+\%3AApotik+Trimulya\%29\&btnG=

Sulardi, P., Hendro, T., \& Umbara, F. R. (2017). Prediksi Kebutuhan Obat Menggunakan Regresi Linier. Prediksi, 57.

Yanto, R., \& Khoiriah, R. (2015). Implementasi Data Mining Dengan Metode Algoritma Apriori Dalam Menentukan Pola Pembelian Obat. Implementasi Data Mining , 103.

Yay, G. G., \& Keçeli, S. (2009). The intersectoral linkage effects in Turkish economy: An application of static leontief model. Panoeconomicus, 56(3), 301-326. https://doi.org/10.2298/PAN0903301G

\section{PROFIL PENULIS}

Penulis Pertama

Rizal Rachman, memperoleh gelar sarjana sains (S.Si), jurusan matematika bidang minat ilmu komputer Unpad, Magister manajemen (M.M) Universitas BSI, Magister komputer di LIKMI Sedang proses.

\section{Penulis Kedua}

Nanang Hunaifi, memperoleh gelar sarjana sains (S.Si), jurusan matematika bidang minat ilmu komputer Unpad, Magister manajemen (M.M) Universitas BSI, Magister komputer di LIKMI Sedang proses. 